\author{
Military Technical College \\ Cairo, Egypt
}

$12^{\text {th }}$ International Conference on Applied Mechanics and Mechanical Engineering

(AMME)

\title{
NATURAL FREQUENCIES OF THIN COMPOSITE PLATES SUBJECTED TO STATIC LOADS
}

\author{
Ahmad. S. B. ${ }^{*}$, Raafat. M. G. ${ }^{* *}$, Tarek. H. E. ${ }^{* *}$ and \\ Ahmad. M. S.
}

\begin{abstract}
The objective of this work is to study the dynamic behavior of thin flat rectangular composite plates when subjected to static loads. A program for calculating the load at first ply fracture was made to estimate the maximum loads that can be carried by each specimen. The natural frequencies of the plate, using finite element program (ANSYS) are obtained considering the fractions of these failure loads. The static deflection corresponding to the applied static loading changes the assumption of straight flat plate to a curved one. An experimental modal test was made to verify the finite element technique. The comparison between numerical and experimental results is carried out. The effect of combined load on the natural frequencies for composite plates with different fiber types, different fiber orientations and at different load locations are estimated.
\end{abstract}

\section{KEY WORDS}

Thin plate, Composite and Natural Frequencies

${ }^{*}$ Professor, Higher Technological Institute, $10^{\text {th }}$ of Ramadan City, Egypt.

${ }^{* *}$ Professor, Dept. Of Mechanical Design, Mataria, Helwan University, Cairo, Egypt.

${ }^{* * *}$ Associate Professor, Dept. Of Mechanical Design, Mataria, Helwan University, Cairo, Egypt.

${ }^{* * * *}$ Egyptian Armed Forces. 


\section{NOMENCLATURE}

\begin{tabular}{|c|c|c|}
\hline$A_{i j}$ & Components of extensional stiffness matrix & $\mathrm{m}^{2}$ \\
\hline$B_{i j}$ & Components of coupling stiffness matrix & $\mathrm{N}$ \\
\hline$D_{i j}$ & Components of flexural rigidity matrix & N.m \\
\hline$E_{L}$ & Longitudinal elastic modulus & \\
\hline $\mathrm{E}_{\mathrm{T}}$ & Transverse elastic modulus & \\
\hline $\mathrm{G}_{\mathrm{LT}}$ & Shear modulus in L-T plane & $\mathrm{N} / \mathrm{m}^{2}$ \\
\hline $\mathrm{h}$ & Lamina thickness & $\mathrm{m}$ \\
\hline $\mathrm{k}$ & Lamina number & \\
\hline $\mathrm{M}_{\mathrm{x}}$ & Bending moment per unit length in $\mathrm{x}$-direction & N.m/m \\
\hline$M_{x y}$ & Torsion moment per unit length in $x-y$ plane & N.m/m \\
\hline $\mathrm{M}_{\mathrm{y}}$ & Bending moment per unit length in y-direction & N.m/m \\
\hline $\mathrm{N}_{\mathrm{x}}$ & Normal force per unit length in $\mathrm{x}$-direction & $\mathrm{N} / \mathrm{m}$ \\
\hline$N_{x y}$ & Shear force per unit length in $x-y$ plane & $\mathrm{N} / \mathrm{m}$ \\
\hline $\mathrm{N}_{\mathrm{y}}$ & Normal force per unit length in y-direction & $\mathrm{N} / \mathrm{m}$ \\
\hline$Q$ & Lamina stiffness matrix & $\mathrm{N} / \mathrm{m}^{2}$ \\
\hline$r, t, s$ & Element coordinate system & \\
\hline $\mathrm{u}, \mathrm{v}, \mathrm{w}$ & Displacement in $\mathrm{x}, \mathrm{y}$ and $\mathrm{z}$ directions & \\
\hline $\mathrm{u}_{\mathrm{i}}, \mathrm{v}_{\mathrm{i}}, \mathrm{w}_{\mathrm{i}}$ & Displacement of node i & \\
\hline$V_{f}$ & Fiber volume fraction & \\
\hline$x, y, z$ & Cartesian coordinates & \\
\hline$z$ & Displacement in Z - direction & \\
\hline$\varepsilon$ & Normal strain & \\
\hline Y & Shear strain & \\
\hline${ }^{\mathrm{v}} \mathrm{LT}$ & Major Poisson ratio & \\
\hline $\mathrm{v}_{\mathrm{TL}}$ & Minor Poisson ratio & \\
\hline$\varphi_{i}$ & Rotation about i direction & \\
\hline$\sigma_{\mathrm{L}}$ & Longitudinal tensile strength & $\mathrm{N} / \mathrm{m}^{2}$ \\
\hline$\sigma_{\mathrm{T}}$ & Transverse tensile strength & $\mathrm{N} / \mathrm{m}^{2}$ \\
\hline$\tau_{\mathrm{LT}}$ & Inplane shear strength & $\mathrm{N} / \mathrm{m}^{2}$ \\
\hline
\end{tabular}




\section{INTRODUCTION}

A composite material is a material having two or more distinct and separate constituent materials combined in a macroscopic structural unit. Many man-made materials are generally not referred as composite if the structural unit is formed at the microscopic level rather than the macroscopic level such as alloys and polymers blends. The composite properties are noticeably different from the constituent properties. The difference will be generally obvious when the volume fraction is greater than $10 \%$ or when a property of one constituent is greater than 5 times. Nowadays composite materials are widely used in many modern industries because of their high strength and stiffness compared to lightweight. Moreover, the primary advantage of these composites is the ability to control anisotropy by design and fabrication [1]. The layers making composite structures may be of different materials, or of the same orthotropic material with the principal material directions of each layer oriented at different angles to the reference axes. The analysis of composite laminates is complicated because of the anisotropic structural behavior that couples in plane deformation to out-of-plane deformation (i.e. bending-stretching coupling) and characteristics of composite materials (e.g., delaminations, matrix cracks, fiber breakage ...etc.) [2]. The classical theory of plate is inadequate in the modeling the dynamic aspects of laminated composite plates because of the assumptions treating plates to be infinitely rigid in the transverse direction by neglecting transverse strain. Since laminated composite materials are often very flexible in shear (and weaker in transverse shear mode), the transverse shearing strains must be taken into account to achieved accurate representation of the behavior of the laminated plate. The plate theories that include transverse shear deformation can be grouped as

1 - the equivalent-single layer plate theories.

2- the layer-wise plate theories.

3 - the individual-layer plate theories.

Concerning global response characteristics such as the maximum deflection, fundamental frequency, or critical buckling load are needed laminate theories can be used. This theories describe the laminate as an equivalent single layer. Otherwise if more accurate information is needed at the ply level or between plies layer-wise theories must be used. However, most analyses of composite laminates utilize single-layer theories which are natural and straightforward extensions of the theories available for homogeneous isotropic plates. Single layer theories are classified into stress based theories or displacement based theories depending on the stress components variation or displacement components variation with respect to thickness coordinate respectively [3 - 8].

For the equivalent-single layer plate theories that include transverse shear deformations, the displacement or stress components are expanded as a linear combination of the thickness coordinate and undetermined functions of position in the reference surface to reduce the 3-D elasticity problem to a two-dimensional. In the displacement-based theories, the three components of the displacement vector are expanded in power series in terms of unknown functions. The principle of virtual displacements or the method of moments is used to derive the equations of equilibrium. In all single-layer plate theories the displacements and strains are continuous through the laminate thickness. This leads to a discontinuous interlaminar 
stress field because of different elastic coefficients at layer interfaces. The stresses based theories are assumed linear variation of the in-plane stresses over the thickness of the plate. The transverse stresses are then obtained from the differential equations of equilibrium. The principle of virtual forces is used to derive the governing equations. The most used displacement based theory is the first order plate theory in which the displacement field is defined as:-

$$
\begin{aligned}
& \mathrm{u}(\mathrm{x}, \mathrm{y}, \mathrm{z})=\mathrm{U}_{\circ}-\mathrm{z} \varphi_{\mathrm{x}} \\
& \mathrm{v}(\mathrm{x}, \mathrm{y}, \mathrm{z})=\mathrm{V}_{\circ}-\mathrm{z} \varphi_{\mathrm{y}} \\
& \mathrm{w}(\mathrm{x}, \mathrm{y}, \mathrm{z})=\mathrm{W}_{\circ}
\end{aligned}
$$

Equation (1), known as the Mindlin plate theory. The functions $U_{0}, V_{0}$, and $W_{0}$ are the displacements along the three coordinates on midsurface and $\varphi_{\mathrm{x}}, \varphi_{\mathrm{y}}$ are the rotation of a transverse normal. Second and higher-order plate theories involve higher-order expansions as the third-order theory in which the displacement model is so chosen that it can explain adequately the parabolic distribution of transverse shear stresses and the non-linearity of the in-plane displacements across the thickness where the displacement field is [8 - 22].

$$
\begin{aligned}
& \mathrm{u}(\mathrm{x}, \mathrm{y}, \mathrm{z})=\mathrm{U}_{\circ}+\mathrm{z}\left(\varphi_{\mathrm{x}_{\mathrm{o}}}-3 / 4(\mathrm{z} / \mathrm{t})^{2}\left(\partial \mathrm{w} / \partial \mathrm{x}+\varphi_{\mathrm{x}_{\mathrm{o}}}\right)\right) \\
& \mathrm{v}(\mathrm{x}, \mathrm{y}, \mathrm{z})=\mathrm{V}_{\circ}+\mathrm{z}\left(\varphi_{\mathrm{y}_{\mathrm{o}}}-3 / 4(\mathrm{z} / \mathrm{t})^{2}\left(\partial \mathrm{w} / \partial \mathrm{y}+\varphi_{\mathrm{y}_{\mathrm{o}}}\right)\right) \\
& \mathrm{w}(\mathrm{x}, \mathrm{y}, \mathrm{z})=\mathrm{W}_{\circ}
\end{aligned}
$$

\section{PLATE STIFFNESS MATRICES}

The stresses in a laminate vary from layer to layer hence it is convenient to deal with a simpler but equivalent system of forces and moments acting on laminate crosssection. The resultant forces acting on a laminate cross-section are obtained by integrating the corresponding stress through the laminate thickness $h$. The resultant moment is obtained by integration through the thickness of the corresponding stress times the moment arm with respect to the midplane.

$$
\begin{aligned}
& {\left[\begin{array}{c}
\mathrm{N}_{\mathrm{x}} \\
\mathrm{N}_{\mathrm{y}} \\
\mathrm{N}_{\mathrm{xy}}
\end{array}\right]=\left[\begin{array}{lll}
\mathrm{A}_{11} & \mathrm{~A}_{12} & \mathrm{~A}_{16} \\
\mathrm{~A}_{12} & \mathrm{~A}_{22} & \mathrm{~A}_{26} \\
\mathrm{~A}_{16} & \mathrm{~A}_{26} & \mathrm{~A}_{66}
\end{array}\right]\left[\begin{array}{c}
\varepsilon^{\mathrm{o}} \mathrm{x} \\
\varepsilon_{\mathrm{y}}^{\mathrm{o}} \\
\gamma^{\mathrm{o}} \mathrm{xy}
\end{array}\right]+\left[\begin{array}{lll}
\mathrm{B}_{11} & \mathrm{~B}_{12} & \mathrm{~B}_{16} \\
\mathrm{~B}_{12} & \mathrm{~B}_{22} & \mathrm{~B}_{26} \\
\mathrm{~B}_{16} & \mathrm{~B}_{26} & \mathrm{~B}_{66}
\end{array}\right]\left[\begin{array}{c}
k_{\mathrm{x}} \\
k_{\mathrm{y}} \\
k_{\mathrm{xy}}
\end{array}\right]} \\
& {\left[\begin{array}{c}
\mathrm{M}_{\mathrm{x}} \\
\mathrm{M}_{\mathrm{y}} \\
\mathrm{M}_{\mathrm{xy}}
\end{array}\right]=\left[\begin{array}{lll}
\mathrm{B}_{11} & \mathrm{~B}_{12} & \mathrm{~B}_{16} \\
\mathrm{~B}_{12} & \mathrm{~B}_{22} & \mathrm{~B}_{26} \\
\mathrm{~B}_{16} & \mathrm{~B}_{26} & \mathrm{~B}_{66}
\end{array}\right]\left[\begin{array}{c}
\varepsilon^{\mathrm{o}} \mathrm{x} \\
\varepsilon^{\mathrm{o}} \mathrm{y} \\
\gamma_{\mathrm{xy}}^{\mathrm{o}}
\end{array}\right]+\left[\begin{array}{lll}
\mathrm{D}_{11} & \mathrm{D}_{12} & \mathrm{D}_{16} \\
\mathrm{D}_{12} & \mathrm{D}_{22} & \mathrm{D}_{26} \\
\mathrm{D}_{16} & \mathrm{D}_{26} & \mathrm{D}_{66}
\end{array}\right]\left[\begin{array}{c}
k_{\mathrm{x}} \\
k_{\mathrm{y}} \\
k_{\mathrm{xy}}
\end{array}\right]}
\end{aligned}
$$

Where

$$
\begin{aligned}
& \mathrm{A}_{\mathrm{ij}}=\sum_{\mathrm{k}=1}^{\mathrm{n}}(\overline{\mathrm{Q}})_{\mathrm{k}}\left(\mathrm{h}_{\mathrm{k}}-\mathrm{h}_{\mathrm{k}-1}\right) \\
& \mathrm{B}_{\mathrm{ij}}=\frac{1}{2} \sum_{\mathrm{k}=1}^{\mathrm{n}}(\overline{\mathrm{Q}})_{\mathrm{k}}\left(\mathrm{h}_{\mathrm{k}}^{2}-\mathrm{h}_{\mathrm{k}-1}^{2}\right) \\
& \mathrm{D}_{\mathrm{ij}}=\frac{1}{3} \sum_{\mathrm{k}=1}^{\mathrm{n}}(\overline{\mathrm{Q}})_{\mathrm{k}}\left(\mathrm{h}_{\mathrm{k}}^{3}-\mathrm{h}_{\mathrm{k}-1}^{3}\right)
\end{aligned}
$$




\section{CALCULATION OF MAXIMUM LOAD AT FIRST PLY FRACTURE}

The maximum load at first ply fracture can be obtained according to the following steps.

1- Transform stiffness matrix to different ply directions.

2- Calculate laminate stiffness matrices $[A],[B]$, and [D].

3- Calculate midplane strains and plate curvatures for the given load.

4- Calculate laminae strains.

5- Transform laminae strains from arbitrary directions to the longitudinal and transverse directions.

6- Calculate laminae stiffness matrix from the laminae elastic properties.

7- Calculate laminae stresses.

For complete laminate analysis used to obtain the load at first ply failure, the first step is to carry out a laminate stress analysis for an assumed unit load on the laminate. Then selecting the maximum stress failure theory which stated that the failure will occur if any of the stresses in the principal material axes exceeds the corresponding allowable stress i.e.

$\sigma_{\mathrm{L}}>\sigma_{\mathrm{LU}}$

$\sigma_{\mathrm{T}}>\sigma_{\mathrm{TU}}$

$\tau_{\mathrm{LT}}>\tau_{\mathrm{LTU}}$

When one of these inequalities is achieved, the material is considered to have failure by a failure mode associated with the allowable stress. compare the laminae stresses with the allowable values and predict the maximum load at which the first ply will fails.

\section{FINITE ELEMENT TECHNIQUES}

The finite element solution is done using ANSYS program where the input data are the elastic module calculated outside the program, dimensions, orientation angle for the laminate and applied static load. The load is a percentage of the predicted first ply fracture load.

The solution begins with the calculation of the static nodal displacements of nodes in $Z$ direction due to applied static load at a specific point, then the displacement at the point where the load is applied is again input to the program for solving the modal (vibration) problem. In such case the nodal displacement of each mode in $\mathrm{Z}$ direction is measured from a new origin point that is achieved due to the effect of the static loading on the plate in $Z$ direction. The element used for the layered application of a plate model has 8-nodes with six degree of freedom at each node. Three translations in $\mathrm{X}, \mathrm{Y}$, and $\mathrm{Z}$ directions and three rotations about the $\mathrm{X}, \mathrm{Y}$, and $\mathrm{Z}$ axes. 

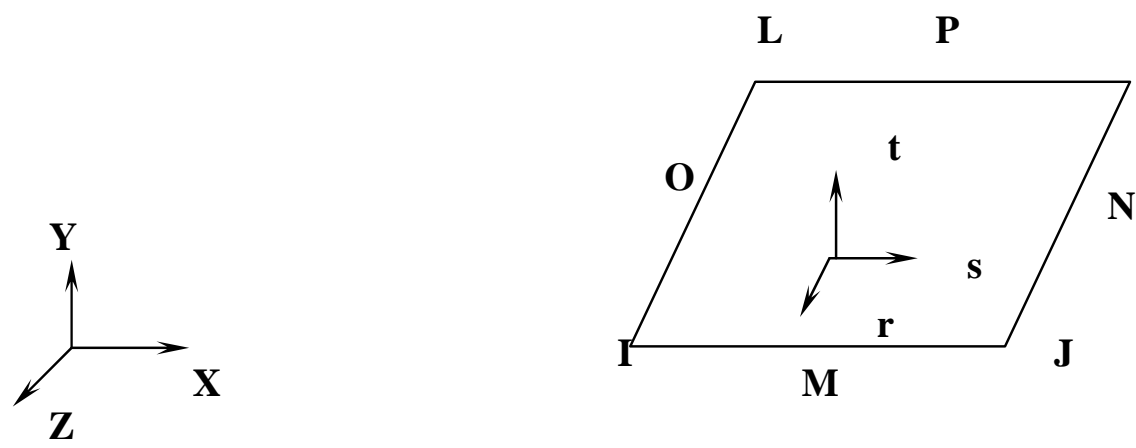

Fig.1.The element geometry, node location, and the coordinate system.

The shape function is

$$
\begin{aligned}
\mathrm{N}_{\mathrm{i}}= & \frac{1}{4}\left[\mathrm{u}_{\mathrm{I}}(1-\mathrm{s})(1-\mathrm{t})(-\mathrm{s}-\mathrm{t}-1)+\mathrm{u}_{\mathrm{J}}(1+\mathrm{s})(1-\mathrm{t})(\mathrm{s}-\mathrm{t}-1)+\mathrm{u}_{\mathrm{K}}(1+\mathrm{s})(1+\mathrm{t})(\mathrm{s}+\mathrm{t}+-1)+\mathrm{u}_{\mathrm{L}}(1-\mathrm{s})(1+\mathrm{t})(-\mathrm{s}+\mathrm{t}-1)\right]+ \\
& \frac{1}{2}\left[\mathrm{u}_{\mathrm{M}}\left(1-\mathrm{s}^{2}\right)(1-\mathrm{t})+\mathrm{u}_{\mathrm{N}}(1+\mathrm{s})\left(1-\mathrm{t}^{2}\right)+\mathrm{u}_{\mathrm{o}}\left(1-\mathrm{s}^{2}\right)(1+\mathrm{t})+\mathrm{u}_{\mathrm{P}}(1-\mathrm{s})\left(1-\mathrm{t}^{2}\right)\right]
\end{aligned}
$$

The results including the fundamental frequencies and mode shapes variation are being investigated in nine points on the area of the plate for clamped-free specimens (Fig.2).

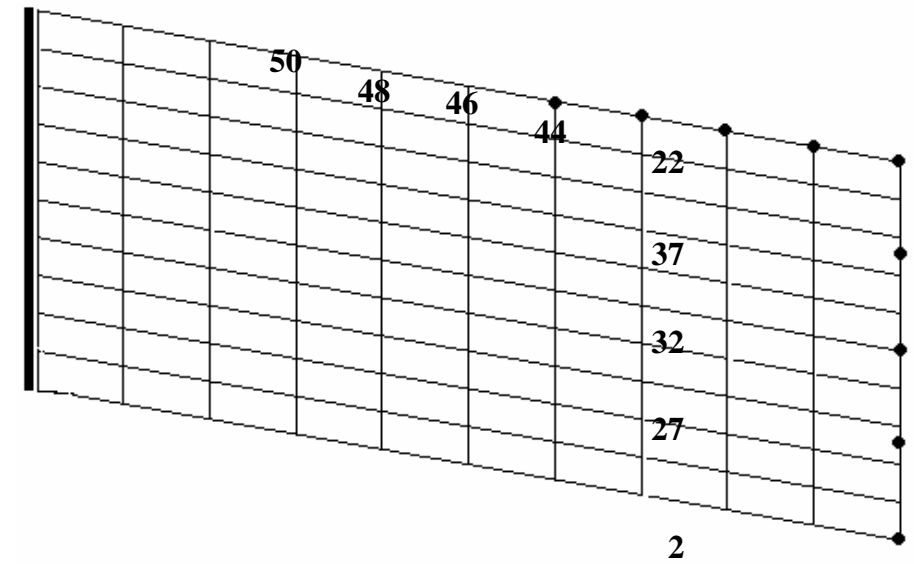

Fig.2 .Node numbering on plate.

\section{NUMERICAL EXAMPLES AND RESULTS}

A complete mechanical properties of the materials used in this work is tabulated in Table (1). The bending and torsion moments at first ply fracture are calculated and tabulated in Table (2) with the fiber orientations. The natural frequencies of the plates with different fiber orientation angles and different fiber types are tabulated in table (3). 
Table 1. Mechanical properties of the materials.

\begin{tabular}{|l|c|c|c|c|}
\hline & Material no. 3 & Material no. 4 & Material no. 5 & Material no. 6 \\
\hline Fiber & Carbon T300 & Boron & E-glass & Kevlar 49 \\
\hline $\mathbf{V}_{\mathbf{f}}$ & 0.6 & 0.6 & 0.6 & 0.6 \\
\hline $\mathbf{E}_{\mathrm{L}}(\mathbf{G p a})$ & 139.248 & 241.25 & 44.655 & 79.848 \\
\hline $\mathbf{E}_{\mathrm{T}}(\mathbf{G p a )}$ & 15.847 & 16.378 & 13.613 & 14.988 \\
\hline $\mathbf{V}_{\mathrm{LT}}$ & 0.272 & 0.272 & 0.284 & 0.362 \\
\hline $\mathbf{V}_{\mathrm{TL}}$ & 0.031 & 0.0185 & 0.0866 & 0.068 \\
\hline $\mathbf{G}_{\mathrm{LT}}(\mathbf{G p a})$ & 4.33 & 4.41 & 3.96 & 4.16 \\
\hline $\boldsymbol{\rho}_{\mathbf{c}}\left(\mathbf{K g} / \mathbf{m}^{\mathbf{3}}\right)$ & 1530 & 2022 & 2010 & 1350 \\
\hline $\boldsymbol{\sigma}_{\mathrm{LU}}(\mathbf{G p a})$ & 2.137 & 1.93 & 2.129 & 2.2 \\
\hline $\boldsymbol{\sigma}_{\mathrm{TU}}(\mathbf{M p a})$ & 52.73 & 52.668 & 53.06 & 52.85 \\
\hline $\mathbf{T}_{\mathrm{LT}}(\mathbf{M p a})$ & 52.71 & 52.657 & 53 & 52.84 \\
\hline
\end{tabular}

Table 2. The bending and torsion moments at first ply fracture.

\begin{tabular}{|l|l|l|l|}
\hline Material & Orientation & $\mathbf{M}_{\mathbf{x}}(\mathbf{N} \cdot \mathbf{m} / \mathbf{m})$ & $\mathbf{M}_{\mathbf{x y}}(\mathbf{N} \cdot \mathbf{m} / \mathbf{m})$ \\
\hline Material No. 3 & $(0,90,0,90)_{\mathrm{s}}$ & 364 & 41 \\
\hline Material No. 3 & $(45,-45,45,-45)_{\mathrm{s}}$ & 81 & 156 \\
\hline Material No. 3 & $(30,-30,30,-30)_{\mathrm{s}}$ & 202 & 174 \\
\hline Material No. 3 & $(0, \pm 45,90)_{\mathrm{s}}$ & 744 & 117 \\
\hline Material No. 4 & $(0,90,0,90)_{\mathrm{s}}$ & 595 & 41 \\
\hline Material No. 5 & $(0,90,0,90)_{\mathrm{s}}$ & 150 & 41 \\
\hline Material No. 6 & $(0,90,0,90)_{\mathrm{s}}$ & 234 & 41 \\
\hline
\end{tabular}

Table 3. The natural frequencies of the plates with different materials and fiber orientation in case of no load.

\begin{tabular}{|c|c|c|c|c|c|}
\hline \multirow{2}{*}{ Material } & \multirow{2}{*}{ Fiber orientation } & \multicolumn{4}{|c|}{ Natural frequencies (Hz) } \\
\cline { 3 - 6 } & $\mathbf{1}^{\text {st }}$ & 39.666 & 75.101 & 247.05 & 303.94 \\
\hline $\begin{array}{c}\text { Material } \\
\text { no.3 }\end{array}$ & $(0,90,0,90)_{\mathrm{s}}$ & 21.598 & 128.05 & 153.68 & 375.97 \\
\hline $\begin{array}{c}\text { Material } \\
\text { no.3 }\end{array}$ & $(45,-45,45,-45)_{\mathrm{s}}$ & 32.392 & 143.11 & 196.05 & 451.62 \\
\hline $\begin{array}{c}\text { Material } \\
\text { no.3 }\end{array}$ & $(30,-30,30,-30)_{\mathrm{s}}$ & 38.452 & 120.42 & 237.38 & 406.57 \\
\hline $\begin{array}{c}\text { Material } \\
\text { no.3 }\end{array}$ & $(0, \pm 45,90)_{\mathrm{s}}$ & 44.900 & 72.775 & 279.32 & 319.66 \\
\hline $\begin{array}{c}\text { Material } \\
\text { no.4 }\end{array}$ & $(0,90,0,90)_{\mathrm{s}}$ & 20.485 & 54.326 & 127.60 & 193.74 \\
\hline $\begin{array}{c}\text { Material } \\
\text { no.5 }\end{array}$ & $(0,90,0,90)_{\mathrm{s}}$ & 32.665 & 72.604 & 203.42 & 274.41 \\
\hline $\begin{array}{c}\text { Material } \\
\text { no.6 }\end{array}$ & $(0,90,0,90)_{\mathrm{s}}$ & & & & \\
\hline
\end{tabular}




\section{EFFECT OF FIBER ORINTATIONS AND LOAD LOCATIONS}

Natural frequencies and mode shapes were studied when the static loads are applied in Z- direction in different nodes along the plate length and width. The static displacement are deduced from applied static constant load at different node locations. The configuration of the plate changes from flat plate to curved plate with new constraints. The results are plotted with respect to the plate length $(\mathrm{L})$ and plate width (W) with different orientation angle. Tables (4) to (7) presents the load location effects on natural frequencies for the materials used and Figures (3) to (8) show the load location effects of different orientation angles. The results show that the load location change along the plate length and width have a considerable effect on the change of natural frequencies. The effect of the fiber orientation angles on the plate rigidity and natural frequencies in no load case was extended to the cases of combined load at different load locations.

Table 4. Load location effect on natural frequencies for material no. $3(0,90,0,90)_{\mathrm{s}}$ along (L) and (W)

\begin{tabular}{|c|c|c|c|c|c|c|}
\hline \multirow[t]{2}{*}{ MATERIAL } & \multirow{2}{*}{$\begin{array}{c}\text { MODE } \\
\text { NO. }\end{array}$} & \multicolumn{5}{|c|}{ LOAD LOCATION ALONG (L) } \\
\hline & & 50 & 48 & 46 & 44 & 22 \\
\hline \multirow{10}{*}{$\begin{array}{c}\text { Material } \\
\text { no. } 3 \\
(0,90,0,90)_{\mathrm{s}}\end{array}$} & 1 & 50.837 & 53.41 & 55.914 & 58.099 & 59.527 \\
\hline & 2 & 181.66 & 232.44 & 246.88 & 227.71 & 189.15 \\
\hline & 3 & 269.63 & 289.98 & 307.57 & 280.09 & 271.81 \\
\hline & 4 & 479.49 & 399.63 & 433.91 & 540.33 & 489.39 \\
\hline & MODE & \multicolumn{5}{|c|}{ LOAD LOCATION ALONG (W) } \\
\hline & NO. & 2 & 27 & 32 & 37 & 22 \\
\hline & 1 & 59.527 & 67.672 & 75.275 & 67.672 & 59.527 \\
\hline & 2 & 189.15 & 181.27 & 163.94 & 181.27 & 189.15 \\
\hline & 3 & 271.81 & 287.51 & 304.01 & 287.51 & 271.81 \\
\hline & 4 & 489.39 & 552.56 & 426.62 & 552.56 & 489.39 \\
\hline
\end{tabular}

Table 5. Load location effect on natural frequencies for material no. 3 $(45,-45,45,-45)_{\mathrm{s}}$ along $(\mathrm{L})$ and $(\mathrm{W})$

\begin{tabular}{|c|c|c|c|c|c|c|}
\hline MATERIAL & MODE & \multicolumn{5}{|c|}{ LOAD LOCATION ALONG (L) } \\
\cline { 2 - 7 } & NO. & 50 & 48 & 46 & 44 & 22 \\
\hline \multirow{4}{*}{$\begin{array}{c}\text { Material } \\
\text { no.3 }\end{array}$} & 1 & $\mathbf{4 5 . 4 1 7}$ & $\mathbf{5 8 . 5 8 9}$ & $\mathbf{7 3 . 9 0 2}$ & $\mathbf{8 2 . 8 5 9}$ & $\mathbf{7 9 . 9 6 9}$ \\
\cline { 2 - 7 } & 2 & $\mathbf{1 4 1 . 5 1}$ & $\mathbf{1 3 7 . 3 9}$ & $\mathbf{1 3 3 . 1 9}$ & $\mathbf{1 3 4 . 4 7}$ & $\mathbf{1 4 0 . 9 3}$ \\
\cline { 2 - 7 } & 3 & $\mathbf{3 1 8 . 7 7}$ & $\mathbf{2 9 3 . 7 5}$ & $\mathbf{2 9 1 . 9 4}$ & $\mathbf{3 2 8 . 2 6}$ & $\mathbf{3 4 0 . 2 1}$ \\
\cline { 2 - 7 } & 4 & $\mathbf{4 0 1 . 8 9}$ & $\mathbf{4 5 6 . 3 8}$ & $\mathbf{4 6 8 . 1 5}$ & $\mathbf{4 1 5 . 2 6}$ & 393.87 \\
\cline { 2 - 7 } & MODE & \multicolumn{5}{|c|}{ LOAD LOCATION ALONG (W) } \\
\cline { 2 - 7 } & NO. & 2 & 27 & 32 & 37 & 22 \\
\cline { 2 - 7 } & 1 & $\mathbf{7 6 . 6 5 3}$ & $\mathbf{8 8 . 9 2 7}$ & $\mathbf{9 4 . 5 9}$ & $\mathbf{9 1 . 4 3}$ & $\mathbf{7 9 . 9 6 9}$ \\
\cline { 2 - 7 } & 2 & $\mathbf{1 4 7 . 8 2}$ & $\mathbf{1 5 4 . 9 1}$ & $\mathbf{1 5 5 . 7 3}$ & $\mathbf{1 4 8 . 2 5}$ & $\mathbf{1 4 0 . 9 3}$ \\
\cline { 2 - 7 } & 3 & $\mathbf{2 9 7 . 4 5}$ & $\mathbf{2 9 9 . 1 8}$ & $\mathbf{2 9 4 . 3}$ & $\mathbf{3 1 9 . 3 8}$ & $\mathbf{3 4 0 . 2 1}$ \\
\cline { 2 - 7 } & 4 & $\mathbf{4 0 9 . 4 8}$ & $\mathbf{4 5 9 . 4 7}$ & $\mathbf{4 6 4 . 4 8}$ & $\mathbf{4 3 3 . 3 1}$ & $\mathbf{3 9 3 . 8 7}$ \\
\hline
\end{tabular}


Table 6. Load location effect on natural frequencies for material no. 3 $(30,-30,30,-30)_{s}$ along $(L)$ and $(W)$

\begin{tabular}{|c|c|c|c|c|c|c|}
\hline \multirow[t]{2}{*}{ MATERIAL } & \multirow{2}{*}{$\begin{array}{c}\text { MODE } \\
\text { NO. }\end{array}$} & \multicolumn{5}{|c|}{ LOAD LOCATION ALONG (L) } \\
\hline & & 50 & 48 & 46 & 44 & 22 \\
\hline \multirow{10}{*}{$\begin{array}{c}\text { Material } \\
\text { no. } 3 \\
(30,- \\
30,30,-30)_{s}\end{array}$} & 1 & 51.439 & 60.162 & 69.401 & 77.306 & 81.573 \\
\hline & 2 & 183.28 & 191.55 & 197.27 & 192.64 & 179.86 \\
\hline & 3 & 322.68 & 324.83 & 312.68 & 313.61 & 318.27 \\
\hline & 4 & 469.29 & 453.21 & 454.48 & 463.66 & 476.07 \\
\hline & MODE & \multicolumn{5}{|c|}{ LOAD LOCATION ALONG (W) } \\
\hline & NO. & 2 & 27 & 32 & 37 & 22 \\
\hline & 1 & 82.008 & 104.96 & 129.59 & 109.83 & 81.573 \\
\hline & 2 & 191.3 & 175.31 & 147.54 & 161.8 & 179.86 \\
\hline & 3 & 296.07 & 353.66 & 362.26 & 375.32 & 318.27 \\
\hline & 4 & 492.78 & 489.82 & 454.9 & 478.18 & 476.07 \\
\hline
\end{tabular}

Table 7. Load location effect on natural frequencies for material no. 3 $(0, \pm 45,90)_{s}$ along $(L)$ and $(W)$

\begin{tabular}{|c|c|c|c|c|c|c|}
\hline \multirow[t]{2}{*}{ MATERIAL } & \multirow{2}{*}{$\begin{array}{c}\text { MODE } \\
\text { NO. }\end{array}$} & \multicolumn{5}{|c|}{ LOAD LOCATION ALONG (L) } \\
\hline & & 50 & 48 & 46 & 44 & 22 \\
\hline \multirow{10}{*}{$\begin{array}{c}\text { Material } \\
\text { no. } 3 \\
(0, \pm 45,90)_{\mathrm{s}}\end{array}$} & 1 & 57.758 & 63.21 & 67.965 & 71.466 & 73.09 \\
\hline & 2 & 193.47 & 221.61 & 237.67 & 227.84 & 203.34 \\
\hline & 3 & 308.98 & 326.29 & 345.05 & 332.05 & 313.29 \\
\hline & 4 & 496.87 & 434.77 & 409.57 & 450.25 & 475.17 \\
\hline & MODE & \multicolumn{5}{|c|}{ LOAD LOCATION ALONG (W) } \\
\hline & NO. & 2 & 27 & 32 & 37 & 22 \\
\hline & 1 & 72.571 & 96.732 & 121.03 & 96.022 & 73.09 \\
\hline & 2 & 201.49 & 184.32 & 155.02 & 183.19 & 203.34 \\
\hline & 3 & 291.27 & 351.43 & 391.46 & 351.05 & 313.29 \\
\hline & 4 & 519.18 & 529.21 & 416.62 & 544.89 & 475.17 \\
\hline
\end{tabular}




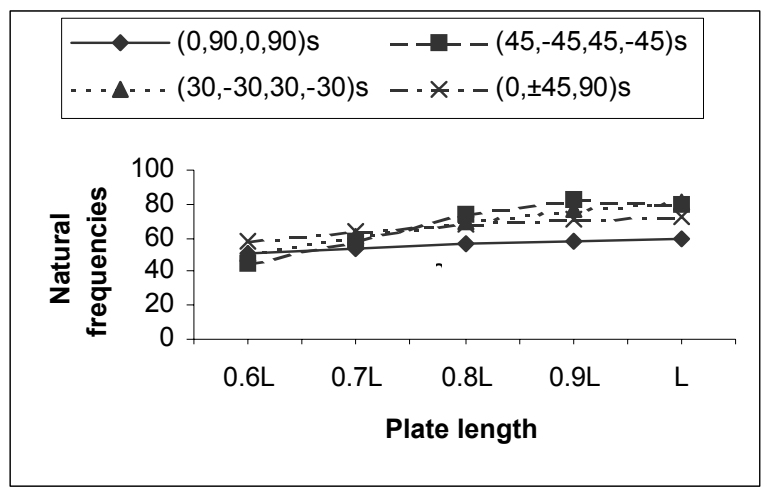

Fig.3. Effect of load location along plate length on $1^{\text {st }}$ natural frequencies for different orientation angles

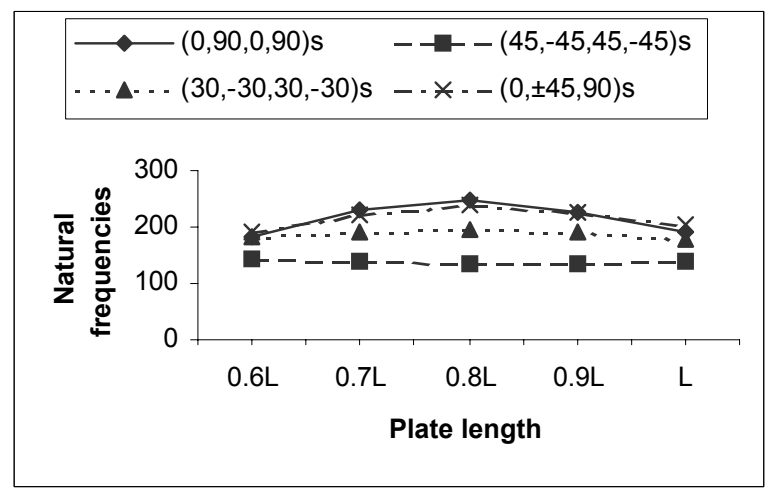

Fig.5. Effect of load location along plate length on $2^{\text {nd }}$ natural frequencies for different orientation angles

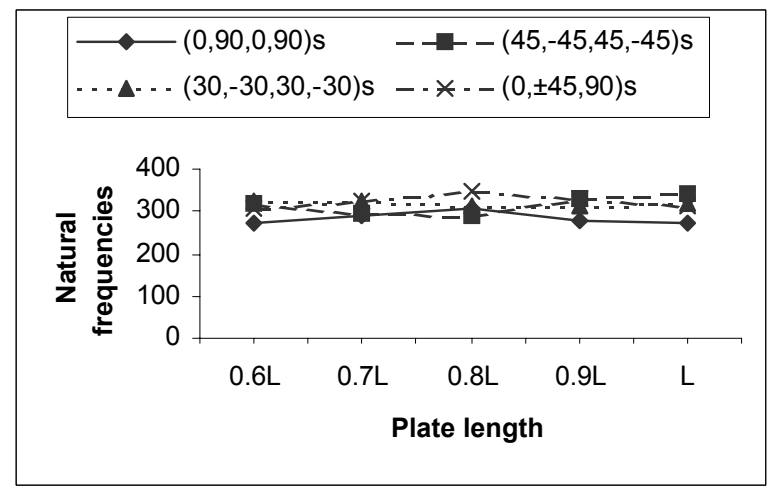

Fig.7. Effect of load location along plate length on $3^{\text {rd }}$ natural frequencies for different orientation angles

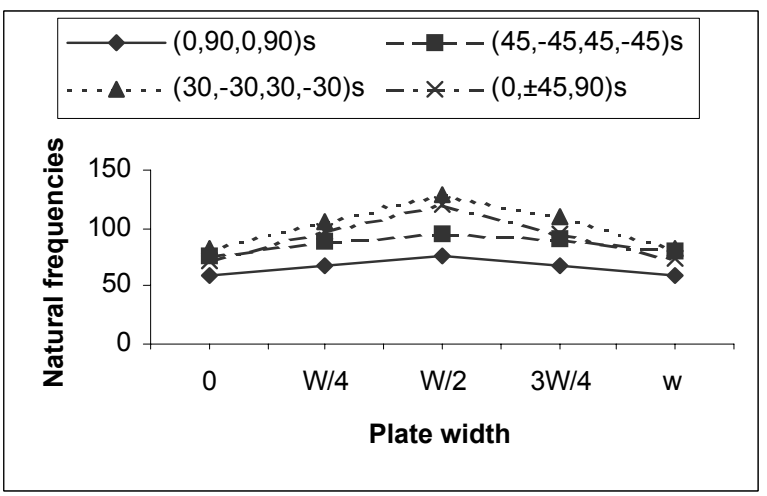

Fig. 4. Effect of load location along plate width on $1^{\text {st }}$ natural frequencies for different orientation angles.

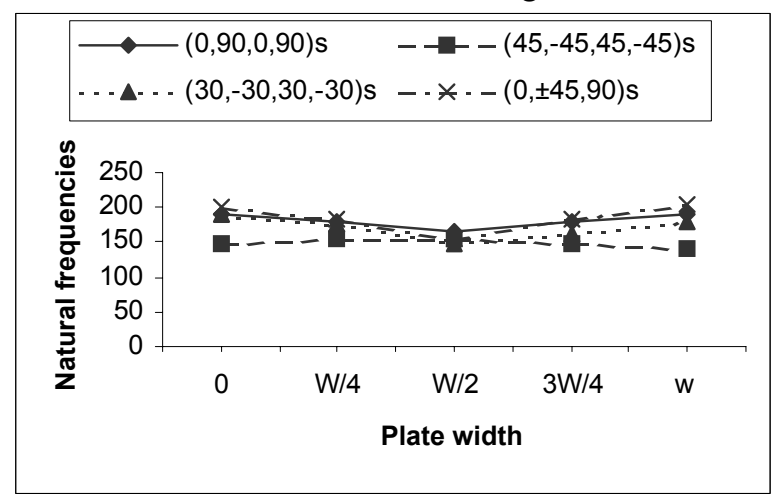

Fig.6. Effect of load location along plate width on $2^{\text {nd }}$ natural frequencies for different orientation angles

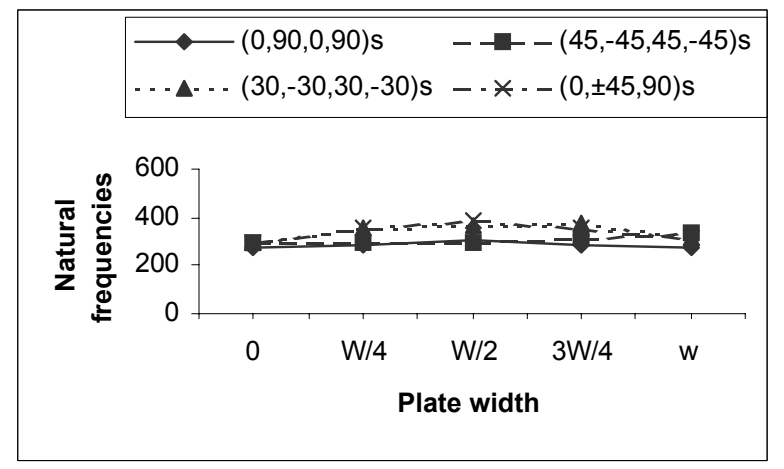

Fig.8. Effect of load location along plate width on $3^{\text {rd }}$ natural frequencies for different orientation angles 


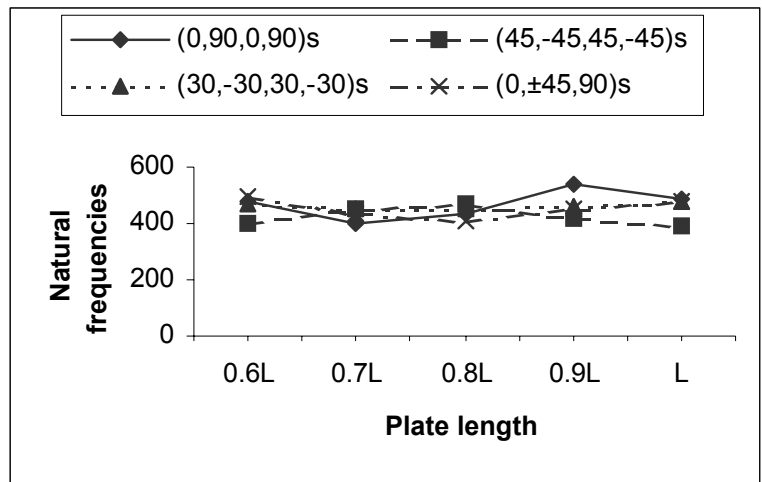

Fig.9. Effect of load location along plate length on $4^{\text {th }}$ natural frequencies for different orientation angles

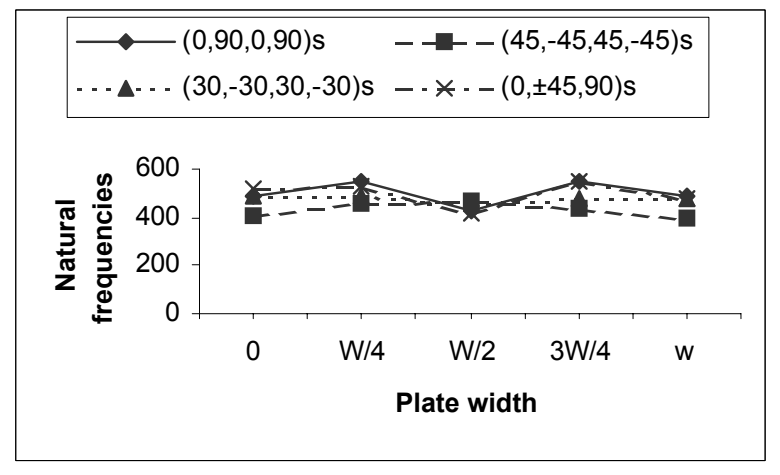

Fig.10. Effect of load location along plate width on $4^{\text {th }}$ natural frequencies for different orientation angles

\section{EFFECT OF FIBER TYPE}

The effects of fiber type are studied for materials no. 3, 4, 5, and 6 with the same fiber volume fractions and fiber orientations $(0,90,0,90)$ s and have fiber type of carbon (T300), Boron, E-glass, and Kevlar 49 respectively. The load was applied at node 22 and is taken 0.05 of the torsion load at first ply fracture of each material.

Table 8. Natural frequencies for materials with fiber type of carbon (T300), Boron, E-glass, and Kevlar 49

\begin{tabular}{|c|c|c|c|c|c|c|c|c|}
\hline \multirow{2}{*}{$\begin{array}{c}\text { MODE } \\
\text { NO. }\end{array}$} & \multicolumn{2}{|c|}{ Boron } & \multicolumn{2}{c|}{ T300 } & \multicolumn{2}{c|}{ Kevlar 49 } & \multicolumn{2}{c|}{ E-glass } \\
\cline { 2 - 9 } & $\mathrm{Hz}$ & $\%$ & $\mathrm{~Hz}$ & $\%$ & $\mathrm{~Hz}$ & $\%$ & $\mathrm{~Hz}$ & $\%$ \\
\hline 1 & $\mathbf{6 0 . 0 6 7}$ & $\mathbf{3 3 . 7 8 0}$ & $\mathbf{5 9 . 5 2 7}$ & $\mathbf{5 0 . 0 7 1}$ & $\mathbf{5 5 . 2 2 4}$ & $\mathbf{6 9 . 0 6 2}$ & $\mathbf{3 9 . 3 4 6}$ & $\mathbf{9 2 . 0 7 2}$ \\
\hline 2 & $\mathbf{2 0 4 . 2 3}$ & $\mathbf{1 8 0 . 6 3 2}$ & $\mathbf{1 8 9 . 1 5}$ & $\mathbf{1 5 1 . 8 6 1}$ & $\mathbf{1 6 3 . 5 9}$ & $\mathbf{1 2 5 . 3 1 8}$ & $\mathbf{1 0 7 . 5}$ & $\mathbf{9 7 . 8 7 9}$ \\
\hline 3 & $\mathbf{2 9 5 . 5 9}$ & 5.825 & $\mathbf{2 7 1 . 8 1}$ & $\mathbf{1 0 . 0 2 2}$ & $\mathbf{2 3 6 . 9 9}$ & $\mathbf{1 6 . 5 0 3}$ & $\mathbf{1 6 1 . 1 4}$ & $\mathbf{2 6 . 2 8 5}$ \\
\hline 4 & $\mathbf{5 2 1 . 7 2}$ & $\mathbf{6 3 . 2 1 1}$ & $\mathbf{4 8 9 . 3 9}$ & $\mathbf{6 1 . 0 1 5}$ & $\mathbf{4 3 3 . 1 7}$ & $\mathbf{5 7 . 8 5 5}$ & $\mathbf{2 9 4 . 2 9}$ & $\mathbf{5 1 . 8 9 9}$ \\
\hline
\end{tabular}

\section{EXPERIMENTAL VARIFICATION}

The experimental work is used to verify the numerical results to ensure the validity of the selected finite element technique. Verifications of the results are done by comparing the natural frequencies measured experimentally with those computed and predicting the error in each case. The specimen was fabricated from carbon fiber and epoxy. The composite layer properties have been listed in Table (9). The plies were stacked in 8 layers with the stacking sequence [0/90/0/90]s and the lamina thickness was $0.156 \mathrm{~mm}$. The overall plate dimension was $101.6 \mathrm{~mm} \times 203.2 \mathrm{~mm}$ (4in $x$ 8in). The results of the no load case and the results of loading at node 22, 46 are tabulated in table (10).

Table 9. Unidirectional lamina properties. 


\begin{tabular}{|l|l|}
\hline Longitudinal young's modulus $\mathrm{E}_{\mathrm{L}}(\mathrm{Gpa})$ & 172.912 \\
\hline Transverse young's modulus $\mathrm{E}_{\mathrm{T}}(\mathrm{Gpa})$ & 7.578 \\
\hline Shear modulus $\mathrm{G}_{\mathrm{LT}}(\mathrm{Gpa})$ & 5.511 \\
\hline Density $\left(\mathrm{gm} / \mathrm{cm}^{3}\right)$ & 1.53 \\
\hline Poisson's ratio $\gamma_{\mathrm{LT}}$ & 0.34 \\
\hline Fiber volume fraction (\%) & 65 \\
\hline
\end{tabular}

Table 10. The experimental results vs. numerical.

\begin{tabular}{|c|c|c|c|}
\hline MODE & $\begin{array}{c}\text { EXPERIMENTAL } \\
\text { FREQUENCIES }\end{array}$ & $\begin{array}{c}\text { NUMERICAL } \\
\text { FREQUENCIES }\end{array}$ & $\begin{array}{c}\% \\
\text { ERROR }\end{array}$ \\
\hline \multicolumn{4}{|c|}{ No load } \\
\hline 1 & 41 & 43.484 & 6.06 \\
\hline 2 & 83 & 83.854 & 1.03 \\
\hline 3 & 239 & 270.92 & 13.36 \\
\hline 4 & 321 & 336.3 & 4.77 \\
\hline \multicolumn{5}{|c|}{ F=1.96N at node 22} \\
\hline 1 & 60 & 62.91 & 4.85 \\
\hline 2 & 232 & 205.35 & -11.49 \\
\hline 3 & 280 & 296.02 & 5.72 \\
\hline 4 & 448 & 524.59 & 17.10 \\
\hline \multicolumn{5}{|c|}{ F=1.96N at node 46 } \\
\hline 1 & 54 & 59.78 & 10.70 \\
\hline 2 & 231 & 270.6 & 17.14 \\
\hline 3 & 299 & 334.59 & 11.90 \\
\hline 4 & 456 & 464.59 & 1.88 \\
\hline
\end{tabular}

\section{CONCLUSIONS}

From the dynamic analysis of the composite thin plates discussed with the various effects included it was found that

- The results of experimental tests show a good agreement with the numerical results and the finite element solution technique could be used effectively in solving the problem.

- The composite plates exhibit an increase in the natural frequencies when statically loaded in Z-direction wherever for all the load locations due to the static deflections, which change of the configuration of flat plate to be curved plate configuration with new constraints.

- For different fiber orientation angle sequences the 1 st natural frequency is increased as the load is moved toward the free end of the plate along the plate length (Figure 3 ) and at the center of the plate width (Figure 4)

- The 2nd natural frequency shows maximum increase at $0.8 \mathrm{~L}$ for all cases except for (45/-45/45/-45) s it shows maximum decrease (Figure 5) and the opposite phenomena is occurs along the plate width (Figure 6).

- The 3rd and 4th natural frequencies show a complex variation along the plate length and width with respect to the fiber orientation angles. 
- It is observed that the composites having high values of EL and GLT (made from fibers of higher modulus such as Boron) show maximum percentage increase in natural frequencies with respect to the natural frequencies of no load case for 2 nd and 4th modes. On the other hand composites having low values of EL and GLT (made from fibers of lower modulus such as E-Glass) shows maximum percentage increase in natural frequencies with respect to the natural frequencies of no load case for 1 st and 3rd modes.

\section{REFERENCES}

[1] EVER J. BARBERO, "Introduction to the Composite Materials Design ", Taylor \& Francis, USA, (1986).

[2] BHAGWAN D. AGARWAL, "Analysis and Performance of Fiber Composites", second Edition, John Willy \& Sons INC., USA, (1990).

[3] AHMED K. NOOR, "Free Vibrations of Multilayered Composite plates", AIAA Journal, Vol. 11, No. 7, (1973).

[4] S.C. PANDA R. NATARAJAN, " Finite Element Analysis of Laminated Composite Plates ", International Journal for Numerical Methods in Engineering, Vol. 14, (1979).

[5] H. KHAYAT, "Free Vibration Analysis of Orthotropic Plates by The Initial Value Method", Computer \& Structure, Vol. 20, No.1, (1985).

[6] D. R. J. OWEN AND Z. H. LI, "A Refined Analysis of Laminated Plates by Finite Element Displacement Method, I-Fundamentals and Static Analysis", Computer \& Structure, Vol. 26, No.6, (1987).

[7] D. R. J. OWEN AND Z. H. LI, "A Refined Analysis of Laminated Plates by Finite Element Displacement Methods-II-Vibration and Stability", Computer \& Structure, Vol. 26, No.6, (1987).

[8] T.KANT AND MALLIKARJUNA, "A Higher-Order Theory for Free Vibration of Unsymmetrically Laminated Composite and Sandwich PlatesFinite Element Evaluations", Computer \& Structure, Vol. 32, No.5, (1989).

[9] J. N. REDDY, "A Review of Refined Theories of Laminated Composite Plates", Shock and Vibration Digest, Vol. 22, No. 7, (1990).

[10] C. K. CHIANG, C. MEI AND C. E JR. GRAY, "Finite Element LargeAmplitude Free and Forced Vibrations of Rectangular Thin Composite Plates", Journal of Vibration, Acoustics, Stress, and Reliability in Design, Vol. 113, No.3, (1991).

[11] J. N. REDDY, "A Review of Refined Theories of Laminated Composite Plates", Shock and Vibration Digest, Vol. 22, No. 7, (1990).

[12] A.NOSIER, R. K. KAPANIA AND J. N. REDDY, "Free Vibration Analysis of Laminated Plates Using a Layerwise Theory", AIAA Journal, Vol. 31, No. 12, (1993).

[13] A.M.ABD-EL-RAOUF, E.E.EL-SOALY, S.M.GHONEAM AND A.A.HAMADA, "Eigen Analysis of Fiber-Reinforced Composite Plates", Composite Structure, Vol. 25, (1993).

[14] A.K.GHOSH and S.S.DEY, "Free Vibration of Laminated Composite Plates - A Simple Finite Element Based on Higher Order Theory", Computer \& Structure, Vol. 52, No.3, (1994).

[15] B.G.HU, M.A.DOKAINISH AND W.M.MANSOUR, "Prediction of Natural Modes of Laminated Composite Plates by a Finite Element Technique", 
Journal of Sound and Vibration, Vol. 181, No. 5, (1995).

[16] NS. BARDELL, JM. DUNSDON AND RS. LANGLEY, "Free Vibration Analysis of Thin rectangular Laminated Plate Assemblies Using The h-p Version of The Finite Element Method", Composite Structure, Vol. 32,(1995)،

[17] G.L.QIAN, S.V.HOA AND X.XIAO, "A New Rectangular Plate Element for Vibration Analysis of Laminated Composites", Journal of Vibration and Acoustics, Vol. 120, (1998).

[18] A. N. NASR AND H. M. NEGM, "Two New Simple Finite Elements for The Static and Dynamic Analysis of Composite Plates", Journal of Engineering Applied Science, Vol. 45, No.5, (1998).

[19] K.OH AND A.H.NAYFEH, "High-to Low-Frequency Modal Interactions in Cantilever Composite Plate", Journal of Vibration and Acoustics, Vol. 120, (1998).

[20] A. A. KHDEIR AND J. N. REDDY, "Free Vibrations of Laminated Composite Plates Using Second-Order Shear Deformation Theory", Computer \& Structure, Vol. 71, No. 6, (1999).

[21] P. AFSHARI AND G. WIDERA, "Free Vibration Analysis of Composite Plate", Journal of Pressure Vessel, Vol.122, No. 3, (2000).

[22] D. J. EWINS, "Modal Testing Theory and Practice", Research Studies Press LTD., UK (1986). 